\title{
NUTRITIONAL EFFECTS OF TANNINS IN ANIMAL FEEDS
}

\author{
J. L. MANGAN
}

AFRC Institute of Animal Physiology and Genetics Research, Babraham, Cambridge CB2 4AT

\section{CONTENTS}

\begin{tabular}{|c|c|c|c|c|c|}
\hline INTRODUCTION & . & - & $\cdot$ & & 209 \\
\hline DISTRIBUTION OF PLANT TANNIN & NS & . & - & & 211 \\
\hline ANALYTICAL METHODS & & $\cdot$ & 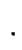 & & 211 \\
\hline RUMINANT ANIMAL NUTRITION & & . & . & & 214 \\
\hline PROTEIN METABOLISM & . & . & . & & 214 \\
\hline SEMI-ARID TROPICAL ECOSYSTEMS & . & . & $\cdot$ & & 219 \\
\hline BLOAT . & . & $\cdot$ & • & & 220 \\
\hline NON-RUMINANT ANIMAL NUTRIT & TION & . & . & . & 222 \\
\hline TRENDS AND CONCLUSIONS. & . & $\cdot$ & $\cdot$ & . & 225 \\
\hline REFERENCES. & . & - & . & & 226 \\
\hline
\end{tabular}

\section{INTRODUCTION}

The term 'tannin' is difficult to define precisely, but the essential property of tannins is that they are naturally-occurring plant polyphenols which combine with proteins and other polymers such as cellulose, hemicellulose and pectin, to form stable complexes. In traditional tanning the collagen chains of hides are crosslinked by tannins to give a durable leather resistent to microbial attack. Tannins proper comprize a relatively small part of a large and diverse group of plant phenolics which range from simple $C_{7}-C_{9}$ phenolic acids such as gallic and coumaric acids, through the $C_{15}$ flavanoids to the highly-polymerized inert lignins. The molecular weight of tannins is usually in the range $500-3000$, requirements being that the tannin is soluble and small enough to orientate itself suitably between the protein chains, but has sufficient phenolic groups to crosslink efficiently under suitable conditions of concentration and $\mathrm{pH}$ (Goldstein \& Swain, 1963). Much confusion exists in the older literature because simple phenolics such as chlorogenic acid which do not have tannin properties in terms of protein precipitation or astringency react with the much-used Folin-Dennis reagent in the same way as true tannins. At the upper end of the molecularweight scale the phenolic polymers become less able to align themselves between protein components as they increase in size. They become less astringent and reactive towards proteins, their solubility decreases and eventually they become bonded to cell-wall components, when they may be measured along with lignin.

Although tannins are chemically a diverse and ill-defined group it is usual to divide them into two types (a) the hydrolysable and (b) the condensed tannins. The hydrolysable tannins consist of a carbohydrate moiety in which the hydroxyl groups are esterified to gallic acid 
(1) or $m$-digallic acid (2) (gallotannins) or hexahydroxydiphenic acid (3) (ellagitannins). These tannins are easily hydrolysed either chemically or by enzymes, e.g. penicillium tannase (EC 3.1.1.20).

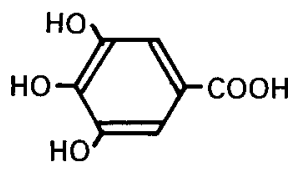

(1) Gallic acid

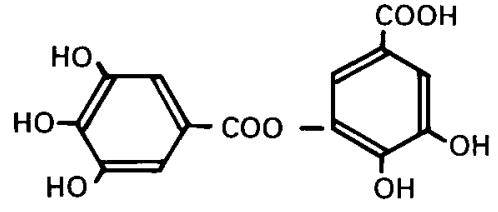

(2) m-Digallic acid

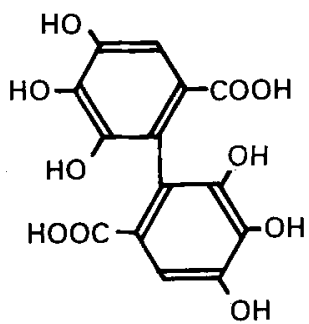

(3) Hexahydroxydiphenic acid

The gallotannins are not widespread, but tannic acid is a well-known example which contains 8-10 mol gallic acid/mol glucose. Recently Haddock $e t$ al. (1982) using highperformance liquid chromatography (HPLC) techniques have thrown considerable light on the structure, metabolism and distribution of gallic acid and hexahydroxydiphenic acidderived tannins.

The condensed tannins are the most widespread and typical of the plant tannins and consist of oligomers of the flavan-3-ols (the catechins) and related flavanol residues which typically produce anthocyanidins (e.g. cyanidin and pelargonidin) on acid degradation. The monomers, which do not themselves have the properties of tannins, have the general structure (4) with substituent groups $R$ or $\mathbf{R}^{\prime}$ consisting of hydrogen or hydroxyl.

The condensed tannins do not have a carbohydrate core like the hydrolysable tannins, but occur as a range of polymers, an example being procyanidin (5).<smiles>[R]c1cc(C(Oc2c(O)c3c(O)c(c2O)C(O)C3)OC(C)O)cc(P)c1O</smiles>

(4) Flavan-3-ol

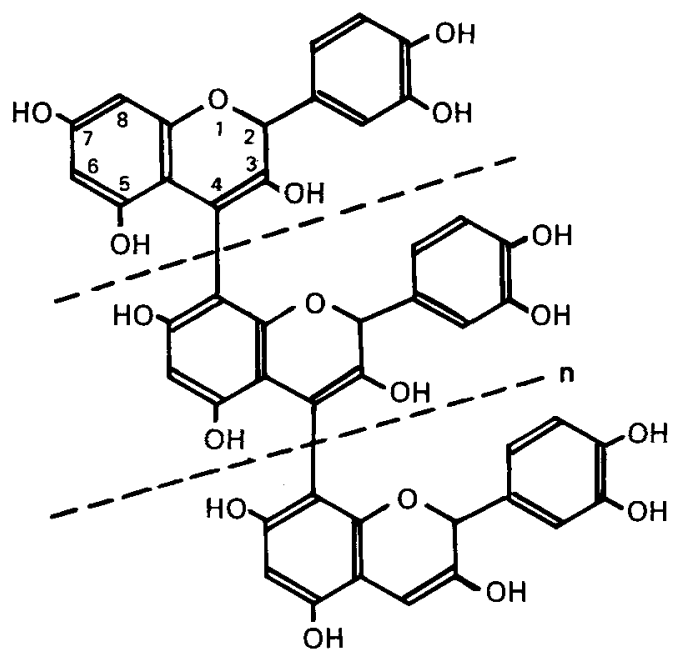

(5) Procyanidin

The reaction of both hydrolysable and condensed tannins with proteins depends on the spatial configuration of the molecules and availability of the reactive phenolic groups. Such spatial relationships contribute to the degree to which different tannins react with proteins 
(Pierpoint, 1983). Different proteins similarly have different affinities for tannins and react most effectively at $\mathrm{pH}$ values close to their isoelectric points (Brown \& Wright, 1964; Hagerman \& Butler, 1978). The concept that protein-tannin interactions are both proteindependent and tannin-dependent was demonstrated by Asquith \& Butler (1986) in a study of the reactions of the procyanidins from Sorghum bicolor L. Moench and Phaseolus vulgaris (pinto bean) and the profisetinidins from Schinopsis lorentzii (quebracho) and Acacia mearnsii (wattle) with a variety of proteins. Such differences may reflect physiological function and confirm that the condensed tannins cannot be considered merely as universal protein-binding agents. Further information on the structure and properties of the tannins may be obtained from recent reviews: Ribéreau-Gayon (1972), McLeod (1974), Harborne et al. (1975), Pierpoint (1983), Mueller-Harvey et al. (1988).

\section{DISTRIBUTION OF PLANT TANNINS}

Although tannins have been known and used in commerce since ancient times their exact nature and distribution in the plant world had not been studied systematically. Well-known sources such as oak (Quercus robur L., $Q$. aegilops, $Q$. ilex), myrobalan (Terminalia chebula, Retz) and sumach (Rhus coriaria L.) exhibited the typical properties of gallo- and ellagitannins. But it is only recently that the metabolism of gallic acid and hexahydroxydiphenic acid in plants has been elucidated using paper chromatography and reversed-phase HPLC, and their distribution and taxonomic importance further investigated (Bate-Smith, 1954; Haddock et al. 1982; Beart et al. 1985). Bate-Smith \& Lerner (1954) showed the distribution of leucoanthocyanins (synonyms condensed tannins, procyanidins) in over 500 species of plants. Jones et al. (1973), Bate-Smith (1973a) and Marshall et al. (1979) also carried out studies on the distribution of condensed tannins in herbaceous legumes, with interests in protein nutrition of ruminant animals and bloat in cattle. Table 1 shows the occurrence of some typical tannins and their nutritional effects.

\section{ANALYTICAL METHODS}

Tannins include a variety of chemical entities and this is reflected in a diversity of methods of analysis, some of which have been used without adequate consideration of their limitations. Hide powder absorption, permanganate oxidation and Dennis-Folin 'totalphenol' reagent are examples of non-specific methods. The vanillin-hydrochloric acid reagent of Bate-Smith (1954) is very sensitive and specific for condensed tannins of the flavan-3-ol and flavan-3,4-diol type. Non-tannin chalcone derivatives and monomeric flavanols also react, but Jones et al. (1973) have used the method effectively in conjunction with gel electrophoresis in a survey of condensed tannins in pasture legumes.

On heating with dilute acid and $n$-butanol, proanthocyanidins are partially converted to the strongly-coloured anthocyanidins. The reaction is only approximately quantitative, but is very specific and cyanidin, delphinidin, pelargonidin and other anthocyanidins are readily identified by paper chromatography and measured spectrophotometrically. The relative-astringency method of Bate-Smith (1973 b) depends on precipitation of the whole protein by haemolysed blood (haemanalysis), as measured by haemoglobin absorption at $578 \mathrm{~nm}$ wavelength, and compared with standard amounts of tannic acid. Results are expressed as tannic acid equivalents (TAE) and give a useful measure of the proteinprecipitating activity of leaf powders or extracts. Marks et al. (1987) have used bovine serum albumin (BSA), $\gamma$-globulin, $\beta$-glucosidase (EC 3.1.1.21) and pancreatic protease under optimum conditions to precipitate tannic acid, and measured the protein in the precipitate by ninhydrin as an alternative to haemanalysis. Results indicate it would be 


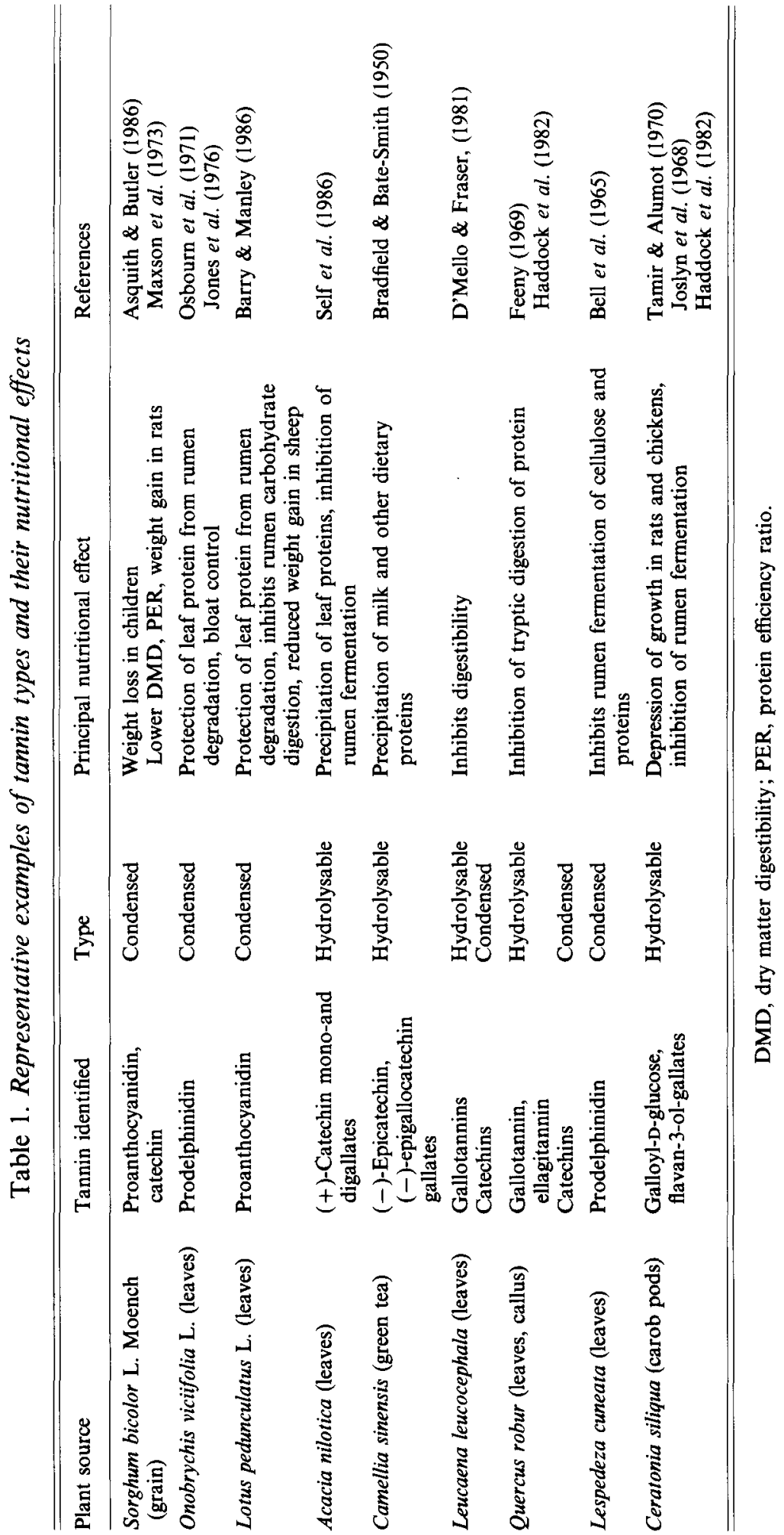


useful in binding studies with pure proteins. In the method of Hagerman \& Butler (1978) condensed and hydrolysable tannins in solution are precipitated by excess BSA and measured with ferric chloride. A number of varieties of sorghum and cowpea (Vigna unguiculata $\mathrm{L}$.) were compared using the vanillin $-\mathrm{HCl}$ and the $\mathrm{FeCl}_{3}$ method. Although ranking of results by these two methods was the same, there were considerable quantitative differences between the two methods. The $\mathrm{FeCl}_{3}$ method was more sensitive to tannic acid than to purified sorghum tannin. Bate-Smith (1954) used a combination of vanillin- $\mathrm{HCl}$ and positive identification of the anthocyanidins after acid degradation. Jones et al. (1976) used aqueous acetone $(700 \mathrm{ml} / \mathrm{l})$ to extract $>95 \%$ of the proanthocyanidins in frozen leaves of legumes, followed by purification on Sephadex G50 columns. Vanillin- $\mathrm{HCl}$ was used to detect flavanols. The condensed tannin fraction was then rechromatographed on a column of Sephadex LH-20. Molecular weights were measured using an analytical ultracentrifuge and cyanidin: delphinidin ratios determined. The analytical methods described give minimal information on molecular structure and many nutritional papers presently published are severely limited by the use of inadequate analytical methods.

HPLC has been used recently to good effect and Beasley et al. (1977) have shown excellent separations of the gallotannins extracted with anhydrous tetrahydrofuran, and also of the galloyl glucose cores produced by methanolysis. This method is highly resolving and quantitative. Mueller-Harvey et al (1987) using HPLC and thin-layer chromatography (TLC) were able to fractionate, characterize and measure complex mixtures of condensed and hydrolysable tannins, flavanoids, catechin gallates and phenolic acids. Total phenolics were precipitated from extracts by ytterbium acetate after the method of Reed et al. (1985), and released from the precipitate for analysis by treatment with oxalate.

Electron-impact mass spectrometry has been used successfully to characterize and elucidate the structure of flavonoids (for review, see Mabry \& Markham, 1975) without derivatization. When gas-liquid chromatography is to be used in conjunction with mass spectrometry (MS), trimethylsilylation or permethylation is required to confer volatility. Details of the diagnostic fragmentation patterns for flavones, chalcones, flavonols, dihydroflavonols, isoflavons and flavanones and numerous applications are given. Self et al. (1986) have applied fast atom bombardment (FAB) MS to plant polyphenols; detailed spectra of ellagi-tannins and gallotannins of oak galls and sumach are given. After fractionation by HPLC the FAB mass spectra of procyanidins of cider apples showed distinctive analytical patterns. HPLC-(FAB)MS applied to the polyphenols of Acacia nilotica, an important African browse species, has separated and characterized a series of flavanol mono- and digallates. Complex dimer and trimer eriodictyol glycosides were also characterized from sorghum tannins. Although complex to interpret, analysis by HPLCMS is rapid and definitive and will amost certainly feature in future analysis of plant polyphenols of nutritional importance. ${ }^{13} \mathrm{C}$ nuclear magnetic resonance (n.m.r.) has also been used (Jacques et al. 1973; Czochanska et al. 1979), for the analysis of polymeric proanthocyanidins and has been used to measure the procyanidin:prodelphinidin ratios, the stereochemistry of the heterocyclic ring of the monomer units and the molecular weights. Czochanska et al. (1980) have studied seventeen species of plants including leaf, root, fruit and bark samples, and provided basic data using ${ }^{13} \mathrm{C}$ n.m.r. The relative amounts of epicatechin, catechin and epigallocatechin derived from the flavan-3-ol terminal group were also determined by gas-liquid chromatography of acid-degradation products. Foo \& Porter (1980) using these techniques have further studied thirty-eight proanthocyanidin polymers (condensed tannins) from fourteen widely-distributed families of plants. Information included procyanidin : prodelphidin ratios, cis:trans ratios in the heterocyclic ring, the molecular weight, the relative amounts of flavan-3-ols in the chain-terminating groups and the proportion of hydrolysable tannin. Only five species studied contained hydrolysable tannins and one contained (-)-epicatechin gallate. These studies confirm that 
procyanidin is the most abundant constituent followed by prodelphinidin, while propelargonidin is only rarely present. With instrumentation for HPLC, MS and n.m.r. now readily available, further information on the structure of tannins and the tannin-protein complexes will increasingly become available for nutritional investigations.

\section{RUMINANT ANIMAL NUTRITION}

\section{PROTEIN METABOLISM}

Although it has been recognized for a long time that excessive degradation of protein in the rumen is undesirable, it is only in recent years that the degradability of protein in the rumen has been considered quantitatively in schemes for assessing protein requirements for animal production. The flow of amino acids absorbed from the ruminant digestive tract, and hence available to the production system being considered, depends on complex interactions governing the extent to which dietary protein is degraded in the rumen, the rate of rumen microbial growth and the rate of outflow from the rumen. Systems proposed by Burroughs et al. (1974), Kaufmann (1977), Jarrige et al. (1978) and the Agricultural Research Council (1980) are factorial systems dependent on average factors derived from practical experiments, while those of Black et al. (1980-81) and Fox et al. (1979) are interactive computer systems. All these systems to varying degrees depend on predicting how much undegraded dietary protein reaches the duodenum.

Soluble proteins such as casein with a linear structure and no crosslinkage degrade very rapidly in the rumen and less than 10\% reaches the duodenum (McDonald \& Hall, 1957). Kinetic studies on the rate of degradation of soluble proteins in the rumen (Mangan, 1972; Broderick, 1978; Nugent \& Mangan, 1981) show characteristics of a pseudo-1st-order reaction, each soluble protein having its own rate of degradation. The most abundant protein in nature is fraction $1(\mathrm{~F} 1)$ leaf protein (ribulose-1,5-bisphosphate carboxylaseoxygenase $E C 4.1 .1 .39$ ) and this protein predominates in the dietary intake of herbivores consuming fresh forage or derivatives such as dried herbage, silage or hay. F1 protein degrades rapidly in the rumen unless protected.

Ferguson et al. (1967) demonstrated that casein could be protected from microbial degradation in the rumen by treatment with formaldehyde and this treatment resulted in increased wool production (Reis \& Tunks, 1969). Zelter et al. (1970) demonstrated that in vitro rumen fermentation of a number of protein concentrates such as soya-bean, sunflower, peanut, linseed, rapeseed and dried lucerne (Medicago sativa) meals could be inhibited by treatment with chestnut (Castanea sativa Mill.) tannins as well as aldehydes. In vivo studies in many places demonstrated quite clearly that formaldehyde treatment led to an increased quantity of dietary amino acids reaching the duodenum undegraded, although 'tannin' in the form of tannic acid did not appear to be effective, e.g. Nishimuta et al. (1974). Ashes et al. (1984) demonstrated, however, that formaldehyde, glutaraldehyde and glyoxal by the process of covalent crosslinking of the proteins made some of the essential amino acids, e.g. lysine, tyrosine and cystine, unavailable for absorption in the small intestine. Complete protection against rumen degradation and high digestibility in the small intestine may not give good results if important amino acids such as lysine and cystine (for wool growth) are selectively destroyed.

The natural occurrence of tannins in pasture species, in addition to its potential for controlling bloat, could have a direct nutritional benefit by protecting leaf protein from degradation in the rumen. F1 leaf protein has a high nutritional value (Mangan, 1982) and the passage of F1-tannin complexes through the rumen which could be digested in the small 
intestine would be of benefit to the animal. The complex between FI protein and the tannin from sainfoin (Onobrychis viciifolia Scop.) has been shown (Jones \& Mangan, 1977) to have simple $\mathrm{H}$-bonding reversible by polyethylene glycol and maximum stability in the $\mathrm{pH}$ range 4-7. Below and above this $\mathrm{pH}$ range the complex is readily dissociated. One would expect, therefore, that the Fl-tannin complex after escaping the rumen fermentation (about $\mathrm{pH}$ 5-7) would be digested readily by the gastric (about $\mathrm{pH} 2.5$ ) and pancreatic (about $\mathrm{pH} 8-9$ ) secretions. This reversible $\mathrm{H}$-bonding has an inherent advantage over protection of dietary protein with formaldehyde in that there is no nutritional damage to important amino acids.

Martin \& Martin (1983) and Martin et al. (1985) showed that in vitro tannic acid, quebracho and oak tannins also effectively precipitate $\mathrm{Fl}$ leaf protein in the $\mathrm{pH}$ range 5.6-7 but above $\mathrm{pH} 7.5$ there is no precipitation. $\mathrm{Ca}^{2+}$ and $\mathrm{Mg}^{2+}$ ions assist precipitation but lysolecithin prevents precipitation at all $\mathrm{pH}$ values. Asquith \& Butler (1986) found that the purified condensed tannins from sorghum, pinto bean, quebracho and wattle have different protein-precipitating powers against ${ }^{14} \mathrm{C}$-labelled $\mathrm{BSA}$ in the ratio $82: 39: 22: 25$ respectively. The tannins also had very different relative affinities for different proteins.

Osbourne et al. (1971) found in practice, however, that the digestibility of sainfoin crude protein (nitrogen $\times 6.25$ ) in the sheep was less than the digestibility of the crude protein of lucerne, and postulated that the condensed tannins of sainfoin reacted with proteins to form insoluble, indigestible protein complexes. In a review of the nutritional value of forage legumes Ulyatt et al. (1977) claimed that in general legumes had a higher nutritive value than grasses and inclusion of white clover (Trifolium repens) in grass pastures often improves the feeding value for sheep and growing calves. Expressed as live-weight gain in lambs, which do not generally suffer from bloat, white clover gave $86 \%$ higher yields than perennial ryegrass (Lolium perenne). Because of the incidence of bloat there are few comparisons between legumes and grasses with adult cattle. Even non-lethal bloat interferes with grazing and the feeding value (nutritive value $\times$ intake) of a pasture with a high white clover content may be less than one with a lower content. In a comparison of live-weight gain of sheep grazing white clover, lucerne and lotus (Lotus pedunculatus var. Maku), the relative live-weight gains were 100:91:77. These marked differences in feeding values can be due to (a) differences in intake and (b) differences in nutritive value. Although comparisons are few (Ulyatt et al. 1977) the dry matter intake of both sainfoin and $L$. pedunculatus are higher than lucerne and their tannin content is not inhibitory. Because the leaf tissue contains a large amount of soluble protein which reacts rapidly with the tannins in the mouth, unpleasant astringency due to possible reaction of salivary proteins with the tannins probably does not occur. In addition the condensed tannin of sainfoin does not form insoluble complexes with submaxillary mucoprotein at $39^{\circ}$ (Jones \& Mangan, 1977) and unpalatability due to astringency would not be expected unless the lubricating properties of the mucoprotein were destroyed.

In a study of the digestion of dietary $\mathrm{N}$ in perennial ryegrass (L. perenne L. var. Ruanui), Italian ryegrass (Lolium multiflorum Lam. var. Tama), White clover ( $T$. repens $\mathrm{L}$. var. Pitan) and giant sainfoin ( $O$. viciifolia Scop. var. Fakir) Egan \& Ulyatt (1980) found that the apparent digestibility of $\mathrm{N}$ in the ryegrass and clover was initially the same at $84-86 \%$, but sainfoin was considerably lower at $69-80 \%$. The amount of $\mathrm{N}$ digested in the stomach was lower with sainfoin, but apparently digestibility of $\mathrm{N}$ in the intestine was also considerably lower, $67-75 \%$, compared with the grass and clover, $81-85 \%$. The overall $\mathrm{N}$ retention, however, was higher for sainfoin than for all the others, either at maintenance or 1.5 times maintenance level of feeding. Live-weight gain and wool growth was reduced in sheep fed on $L$. pedunculatus grown in low-fertility soil conditions and containing 
76-90 g condensed tannin/ $\mathrm{kg}$ dry matter (DM) compared with the same cultivar grown under good conditions and having a low tannin content of $20 \mathrm{~g} / \mathrm{kg} \mathrm{DM}$ (Barry, 1985).

By growing $L$. pedunculatus under conditions of high and low soil fertility Barry \& Duncan (1984) and Barry \& Manley (1984), were able to induce low (46 g/kg DM) and high $(106 \mathrm{~g} / \mathrm{kg} \mathrm{DM})$ concentrations of condensed tannins in the herbage. It was found that with sheep the voluntary intake of digestible organic matter (DOM) and metabolizable energy (ME) was significantly lower $(P<0.05)$ with the high-tannin lotus. By spraying high-tannin lotus with polyethylene glycol (PEG; molecular weight (MW) 3350) to combine with the condensed tannin (see Jones \& Mangan, 1977) the total reactive tannin content was reduced from 63 to $7 \mathrm{~g} / \mathrm{kg} \mathrm{DM}$ and this resulted in significant increases in voluntary intake of DOM, ME, digestible fibre $(P<0.05)$ and digestible total $\mathrm{N}(P<0.01)$. Apparent digestibility of DM and $\mathrm{ME}(P<0.001)$, cellulose $(P<0.05)$, hemicellulose $(P<0.01)$ and total N $(P<0.001)$ was also significantly increased. As the only difference was the addition of PEG to the herbage, there can be little doubt that the presence of condensed tannins in lotus has a major effect both on the voluntary intake and the nutritive value. These authors differentiated between 'total reactive tannin' and 'free tannin', the latter being that proportion of the total reactive tannin which remained free in solution after total maceration of the leaf tissue, i.e., not bound as insoluble protein-tannin complexes. The depression in hemicellulose digestion in the previously-decribed experiments probably was due to the free tannin $(5.4 \mathrm{~g} / \mathrm{kg} \mathrm{DM})$ which would be released into the rumen fluid and is known to inhibit microbial enzymes (see Feeny, 1969). In both the low- and high-tannin lotus there were gains of 1.8 and $10.5 \mathrm{~g}$ total $\mathrm{N} / \mathrm{d}$ across the rumen, compared with a predicted loss of 3.7 and $2.1 \mathrm{~g}$ total $\mathrm{N} / \mathrm{d}$ for non-tannin species at the same $\mathrm{N}$ intake; the post-rumen digestion of non-ammonia-N (NAN) was only slightly less, 71 and $67 \%$ respectively, than published values for white clover, $76 \%$ and NAN apparently digested in duodenum of 0.71 and $0.91 \mathrm{~g} / \mathrm{g}$ total $\mathrm{N}$ feed intake respectively; clearly indicating an advantage for the higher tannin content lotus. Combining their results with the L. corniculatus results of John \& Lancashire (1981) significant linear relationships were proposed:

$$
\begin{array}{rll}
D=0.79 & (\text { SE 0.016) }+0.0052 C(\text { SE 0.00027) } & (r 0.997), \\
P R=0.57 \quad(\text { SE 0.008) }+0.0032 C(\text { SE 0.00015) } & (r 0.998),
\end{array}
$$

where $C$ is condensed tannin concentration, $D$ is duodenal NAN flow per unit total $\mathrm{N}$ intake, $\mathrm{PR}$ is post-ruminally digested NAN per unit $\mathrm{N}$ intake.

From the plot of these values $D$ becomes unity, i.e., all the dietary $\mathrm{N}$ passes through the rumen and appears at the duodenum, at a value for $C$ of $40.8 \mathrm{~g} / \mathrm{kg} \mathrm{DM}$.

In growth trials of young sheep grazing pure forage species, John \& Lancashire (1981) obtained relative growth rates on white clover $1 \cdot 9$, lotus $(L$. corniculatus $) 1 \cdot 7$, lucerne $1 \cdot 7$, red clover (Trifolium pratense) 1.5 and perennial ryegrass 1.0 . The plots were on highfertility soil and by analogy with similar plots the lotus probably contained about $20 \mathrm{~g}$ condensed tannin $/ \mathrm{kg} \mathrm{DM}$. At higher tannin concentrations in L. pedunculatus $(80 \mathrm{~g}$ total and $9 \mathrm{~g}$ free condensed tannin/kg DM) Barry \& Duncan (1984) found that lamb growth was increased by daily drenching with $100 \mathrm{~g}$ PEG. Control plots with red and white clover gave no response with PEG drenching, showing that the lotus effect was due to tannins. It was concluded that the precise concentration of tannin in the forage was an important factor in obtaining optimum results. Barry \& Manley (1986) investigated the interrelationships between total condensed tannins (TCT), free condensed tannins (FCT) and lignin of lotus on the theory that the reacted condensed tannin-protein complex (TCTFCT) was beneficial in allowing dietary true protein to reach the duodenum undegraded, but that FCT inhibited rumen fermentation of hemicellulose and other desirable 
fermentation functions, and lignin has a well-recognized inhibition of digestibility of herbage.

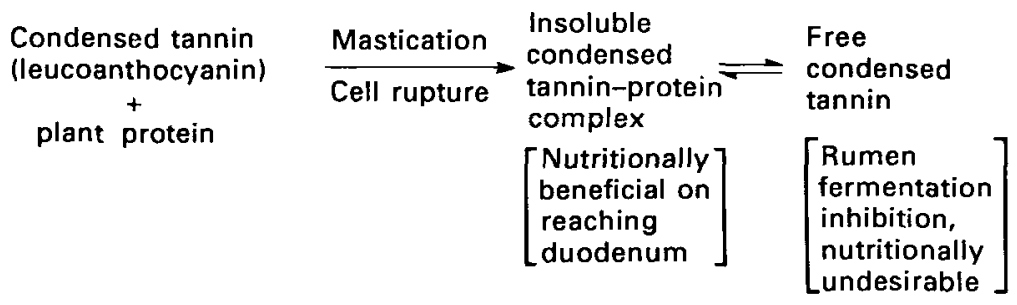

A linear equation for different populations of $L$. pedunculatus and $L$. corniculatus with total condensed tannins up to $90 \mathrm{~g} / \mathrm{kg}$ DM was proposed:

$$
\text { FCT }=0.15+0.099 \text { TCT } \quad(r 0.856, n 14, P<0.001),
$$

and for total condensed tannins above $90 \mathrm{~g} / \mathrm{kg}$ DM by:

$$
\mathrm{FCT}=-61.3+0.73 \mathrm{TCT} \quad(r 0.797, n 5, P<0.10) .
$$

Similarly the lignin (L) and total condensed tannins were related, by

$$
\text { TCT }=-98 \cdot 1+1 \cdot 07 \mathrm{~L} \quad(r 0 \cdot 845, n 8, P<0 \cdot 01) .
$$

It should be noted, however, that the condensed tannins of different species have different physical and chemical properties. Thus lotus tannin has a MW of 6800-7100 and a delphinidin:cyanidin ratio of $77: 23$, but sainfoin tannin has a much larger MW (17000-28 100) and a delphinidin : cyanidin ratio of 81:19 (Jones et al. 1976). The equations quoted previously may therefore require some adjustment for other species, as indicated by the different relative astringency, i.e., protein-precipitating power, of different tannins. Bate-Smith (1973a) found values for relative astringency of the tannins of Hedysarum multijugum Maxim 0.45, Lathyrus pratensis L. 0.7, Onobrychis viciifolia Scop. 0.75, Trifolium arvenie L. $0 \cdot 94, L$. corniculatus L. 1.1. Jones et al. (1976) found that astringency of Trifolium affine and $T$. arvense $<L$. pedunculatus $<$ Coronilla varia $<T$. repens (flower), which was in order of their prodelphinidin content. However, sainfoin tannin with the highest prodelphinidin content was the least astringent, but its anomalous position was explained by its exceptionally-high MW. The technique of complexing condensed tannins with PEG for in vivo experiments is probably valid because the complex is very stable, does not react with the vanillin- $\mathrm{HCl}$ test and is excreted unchanged in the faeces.

By spraying $L$. pedunculatus $\mathrm{L}$. with differing amounts of PEG, MW 3350, Barry et al $(1986 \mathrm{~b})$ were able to adjust the total reactive condensed tannin concentration to 95,45 and $14 \mathrm{~g} / \mathrm{kg}$ DM with corresponding free condensed tannin of 15,5 and $2 \mathrm{~g} / \mathrm{kg}$ DM and studied the digestion in sheep. With increasing concentrations of reactive condensed tannin there was a linear increase of NAN to the duodenum, but a linear decrease in digestibility of energy and organic matter. The rumen digestion of hemicellulose, but not of cellulose was also decreased. With increased condensed tannin concentration there was an increase in $\mathbf{N}$ retention. The rate of hemicellulose digestion was found to be rate-limiting for cellwall components. The increase in tannin content did not affect this, but increased the rate at which their undegraded residues left the rumen. It was concluded that the optimum concentration of condensed tannin in lotus should represent a balance between the positive effect of increasing $\mathrm{N}$ digestion, and the negative one of decreasing rumen carbohydrate digestion, and a desirable value of $30-40 \mathrm{~g} / \mathrm{kg}$ DM was proposed.

The concentration of condensed tannin in L. corniculatus L. ranges from 2.5 to $106 \mathrm{~g} /$ $\mathrm{kg} \mathrm{DM}$ and Waghorn et al. (1987a) compared digestion in sheep with two cultivars, Empire 
with a low tannin content of 4.6-5.9 $\mathrm{g} / \mathrm{kg} \mathrm{DM}$ and Maitland with a medium tannin content of $32.9-34.8 \mathrm{~g} / \mathrm{kg}$ DM. In vitro maceration of the tissue of these varieties showed that 95 and $5 \%$ respectively of the $\mathrm{F} 1$ leaf protein was soluble, indicating that Maitland had sufficient tannin to precipitate virtually all the soluble leaf protein, but with Empire there was very little effect. This was reflected in a larger rumen NAN pool in sheep fed on Maitland $(P<0.05)$ and a lower rumen ammonia concentration $(P<0.005)$. The proportion of feed $\mathrm{N}$ digested in the stomach was always lower $(P<0.01)$ with Maitland and the microbial $\mathrm{N}$ flux to the duodenum was lower, but not significantly so. Apparent $\mathrm{N}$ absorption from the intestines was similar in the two cultivars and the higher $\mathbf{N}$ retention with Maitland appeared to be due to better utilization of absorbed $\mathrm{N}$ rather than increased absorption. When PEG was infused $(50 \mathrm{~g} / \mathrm{d})$ into the rumen of sheep fed on Maitland for $10 \mathrm{~d}$, it was found that the rumen ammonia concentrations in the control sheep were lower than in the PEG-infused sheep, although the $\mathbf{N}$ intake was the same. The flux of $\mathbf{N}$ was higher at the abomasum, ileum and faeces of the control sheep than in the PEG-infused sheep. The flux of amino acids in the control sheep was $164 \mathrm{~g} / \mathrm{d}$ or $78 \%$ of intake and in PEG-infused sheep this was reduced to $124 \mathrm{~g} / \mathrm{d}$ or $60 \%$ of intake. In addition the proportion of essential amino acids was greater in the control sheep.

In a similar experiment Waghorn et al. $(1987 \mathrm{~b})$ confirmed the lower rumen ammonia in the control sheep over the PEG-infused sheep when fed on L. corniculatus L. (cv. Maitland). Abomasal flux of amino acids (AA) were 167 and $133 \mathrm{~g} / \mathrm{d}$ for control and PEGinfused sheep, indicating a 22 and $40 \%$ loss of AA respectively. Individual AA showed some quantitative differences, but the flux through the abomasum and apparent absorption of individual AA from the small intestine was significantly greater for most AA for the control sheep than for the PEG-infused sheep.

An important specific effect on carcass composition has been reported by Purchas \& Keogh (1984) in a series of five grazing trials on L. pedunculatus Cav. (var. Grasslands Maku) and white clover, T. repens L. (var. Grasslands Huia). Although white clover had a somewhat greater $(+15 \%)$ growth rate, the lotus-fed groups grew satisfactorily and consistently produced carcases with decreased fatness, an important component of the New Zealand grading system for export lamb. It appeared that control of rumen fermentation and increase in flux of dietary protein to the duodenum, due to the tannins in the lotus, had altered the balance of energy: protein and produced more meat in keeping with present-day nutritional requirements of humans.

The effect of the presence of condensed tannins in herbage on the endocrine system and adipose tissue metabolism in sheep has been investigated by Barry et al. (1986a). There was a linear and positive correlation between condensed tannin concentration and growth hormone $(\mathrm{GH})$ and a negative correlation with 3, 5, 3'-tri-iodothyronine. Other hormones, thyroxine, insulin-like growth factors (IGF I and IGF II), prolactin, somatostatin, insulin and glucagon showed no response. $\mathrm{GH}$ increases $\mathrm{N}$ retention and lipid turnover (Muir $e t$ al. 1983) and it was suggested that condensed tannin, either the free tannin or that released when the protein-tannin complex was digested, reacted with gut-wall proteins and stimulated GH secretion. In the lotus used in these experiments about $10 \%$ of the total tannin was free tannin. Increased GH secretion could be a factor in the increased $\mathbf{N}$ retention in the lotus-fed sheep. There was an increase in lipolysis, measured by the rate of glycerol release, with a reduction of the lipogenesis: lipolysis ratio, leading to lower fat deposition. The increase in lipolysis and $\mathrm{GH}$ secretion were both reduced by incorporation of PEG into the lotus feedstuff. 


\section{SEMI-ARID TROPICAL ECOSYSTEMS}

Browse plants constitute a major source of feedstuff for livestock in arid and semi-arid regions, particularly in Africa, North America and Australia. They are complementary to the grasses especially during the non-growing season, and often provide essential protein when grasses have dried out (Le Houérou, 1980). The high concentration of phenolic compounds, including tannins, particularly under conditions of low soil fertility (Barry \& Duncan, 1984), drought and high temperatures, contribute to unpalatability and nutritional inadequacy for browsing livestock such as cattle, camels, goats and sheep. Wildlife may also be affected and Van Hoven (1984) found that during a drought cycle in Southern Africa the Greater Kudu suffered highest mortalities in 'fenced in' game ranches, in spite of the presence of reasonable amounts of browse. It was found that the normal selection of browse species was negatively related to their tannin content. Examination of forty kudu browse species showed that in vitro digestibility of DM was inversely related to their tannin content. Within the range of $0-25 \%$ total tannin the DM digestibility has an inverse curvilinear relationship from approximately $70 \%$ to below $20 \%$. It was concluded that kudu could die from malnutrition when their selection of browse was limited by fencing, and they were obliged to consume plants with a high tannin content over a long period. Recently extensive information on the chemical composition and nutritive value of browse species in semi-arid regions has become available (Le Houérou, 1980) and although tannins and other secondary metabolities were not considered in that study they were known to be widespread in acacias and other leguminous shrubs (Bate-Smith \& Lerner, 1954). The energy content of browse is very low and cannot generally meet maintenance requirements for cattle, although it can for sheep. For goats, however, browse is adequate for production. Many Boscia and Acacia have high protein contents and although others such as the Bombaceae and Rhamnaceae have marginal values, in general African browse species appear adequate with regard to protein (Le Houérou, 1980).

This assumption of protein adequacy is based, however, on estimates for temperate species (Demarquilly \& Weiss, 1970) and application to high-tannin browse under arid conditions may not be correct. Thus D'Mello \& Fraser (1981) showed that leaf meal of Leucaena leucocephala contained 22-34 g 'gallotannic acid' and 12-44 g 'catechin' $/ \mathrm{kg} \mathrm{DM}$ which may affect digestibility and growth in addition to causing problems due to its mimosine content. Using HPLC and FAB-MS, Self et al. (1986) have shown that approximately $77 \%$ of the total polyphenols of Acacia nilotica, an important Ethiopian browse species, consists of four flavanol monogallates and two flavanol digallates. The possible release of gallic acid during digestion could be an animal health problem. MuellerHarvey et al. (1987) used HPLC and TLC to characterize the phenolic compounds present in ten Ethiopean browse species. A. nilotica and Pterolobium stellatum contained virtually no leucoanthocyanins, but several condensed tannins of the $(+)$-catechin-gallate type. Rhus natalensis contained one or more ellagi-tannins. Euclea schimperi, Acacia bussei and Acacia seyal were all similar in their tannin content, predominantly prodelphinidins, but with gallic acid and ellagic acid esters. Albizia amara, Acacia brevispica and Acacia drepanolobium all contained lower amounts of condensed tannins, flavonol glycosides and flavonols than the previously-mentioned species. Prodelphinidins were present in all three and procyanidin in A. drepanolobium. Cadaba farinosa contained small quantities of a large number of non-tannin phenolics, the main one being kaempferol. This analysis of a small number of species indicates the complexity of the ecosystem and shows that a considerable research effort will be required to completely evaluate the nutritonal plant-animal interactions. The toxic effects of the hydrolysable tannins may outweigh the rumen proteinprotecting properties of the condensed tannins. The anti-nutritional effects of large 
amounts of soluble phenolics, as precipitated by ytterbium, was demonstrated in a sheep trial by Reed \& Soller (1987). Acacia cyanophylla, Acacia sieberiana, A. seyal, Sesbania sesban and Vicia dasycarpa were fed to provide a growth rate of $50 \mathrm{~g} / \mathrm{d}$ with tef (Eragrostis tef) straw ad lib. These plants contained soluble phenolics at 390,480, 400, 180 and $190 \mathrm{~g} / \mathrm{kg}$ DM respectively. Growth rate with $S$. sesban and $V$. dasycarpa were near the expected values for non-tannin plants. With $A$. sieberiana growth rate was halved and with A. cyanophylla there was a negative growth rate $(-14 \mathrm{~g} / \mathrm{d})$, and these values were reflected in their $\mathrm{N}$ retentions and digestibilities. With $A$. seyal growth was not significantly depressed, although the soluble phenolics were high. The increased faecal $N$ excretion was offset by decreased urinary excretion, probably by increased endogenous urea recycling. Murdiati \& McSweeney (1987) have shown that the hydrolysable tannins of Terminalia oblongata and Clidemia hirta, and also tannic acid, reacted with casein in the $\mathrm{pH}$ range 3-5 and with pepsin in the $\mathrm{pH}$ range 4-6. Thus the hydrolysable tannins react with proteins under conditions found in the abomasum rather than in the forestomach, and may interfere with the normal digestion of proteins, in contrast to the condensed tannins which form stable complexes only at rumen pH (Jones \& Mangan, 1977). The difficulty of interpreting digestibility of these species in nutritional terms was demonstrated by Wilson (1977) who showed that some species with high digestibilities, Atriplex nummularia (69\%), Maireana pyramidata $(58 \%)$ and Geijera parviflora $(59 \%)$, had very low voluntary intakes by sheep and goats, whereas Casuarina cristata with a poor digestibility of $29 \%$ and a low availableprotein content of $6.5 \%$ was readily eaten, resulting in high organic matter intakes. Digestibility of some species could only be measured in vivo by difference after admixture with a large proportion of lucerne chaff. Mueller-Harvey et al. (1988) have reviewed the effects of phenolics in fibrous crop residues and plants on the digestion of proteins and carbohydrates of ruminants, with particular emphasis on species in semi-arid regions.

Lespedeza cuneata (syn. Sericea) has long been recognized as a useful cattle forage in the drier parts of the USA, although inferior in nutritive value to lucerne. Lespedeza contains large quantities of a leucodelphinidin, 'sericin', claimed to have specific inhibitory activity against cellulase (EC 3.2.1.4) and pectinase (EC 3.2.1.15) (Bell et al. 1965). Smart et al. (1961) showed that the cellulase activity of strained rumen fluid against carboxymethyl cellulose as substrate could be completely inhibited with an aqueous extract of $L$. cuneata. Comparing nine varieties of Lespedeza, Cope \& Burns (1971) found that a low-tannin variety $(27.7 \mathrm{~g}$ tannin $/ \mathrm{kg})$ has a higher in vitro DM digestibility (DMD), $38.6 \%$, than a variety with high tannin $(37.6 \mathrm{~g} / \mathrm{kg})$ and $26.8 \%$ DMD. Both high- and low-tannin varieties on addition of sericin gave progressively lower digestibility, down to values ranging from $9 \cdot 2$ to $12 \cdot 7 \%$. Tall fescue (Festuca arundinacea Schrieb.) used as standards had in vitro digestibilities of DM ranging from $51 \cdot 7$ to $64.4 \%$.

\section{BLOAT}

Bloat is a widespread disorder when cattle and sheep are fed on a number of the most valuable and productive legume forages such as lucerne, white clover, red clover, subterranean clover (Trifolium subterraneum) and occasionally the lush spring growth of grasses. The physiological factors in the bloat syndrome have been extensively studied (for review, see Clarke \& Reid, 1974) and although complex the disorder is primarily due to a stable foam, forming in the reticulo-rumen, in which rumen fermentation gases are entrapped. The free gas space normally present in the dorsal sac of the rumen is replaced by a frothy mass of rumen digesta. Unless this condition is relieved the animal suffers severe compression of heart and lungs, leading to anoxia and rapid death. In the U.K. and other developed countries the reluctance to use legumes in pastures carries an economic penalty which is not evaluated. Prevention of bloat has been partially achieved by treatment with 
anti-foaming oils and non-ionic detergents (Reid et al. 1961), administered by drenching, spraying of pastures, by trocar and cannula or by intrarumen slow-release devices. These control methods, however, all present difficulties with a high cost in labour or materials.

The active foaming agent in this disorder is soluble leaf 'cytoplasmic' protein, the main component of which is Fl (ribulose-1,5-bisphosphate carboxylase) (Mangan, 1959; McArthur et al. 1964; Stifel et al. 1968; Jones \& Lyttleton, 1969). Bloat provoking species such as lucerne and white and red clover release large amounts of soluble protein into the rumen, but non-bloating species such as sainfoin and $L$. corniculatus $\mathrm{L}$. do not, due to their content of condensed tannins (Kendall 1966; Jones et al. 1970, 1973). This involvement of $\mathrm{Fl}$ protein, which is the most abundant protein in green leaves makes a direct connection between the problem of bloat and the protein nutrition of forage-fed ruminants (for review, see Mangan, 1982).

The reaction between the condensed tannins and the soluble protein of leaves occurs in the mouth of cattle during mastication. Mangan et al. (1976) by collecting the food bolus at the cardia showed that large quantities of the soluble protein $(20-28 \%)$ were released from lucerne, ryegrass and red clover before the food bolus reached the rumen, but with sainfoin no soluble protein could be detected unless PEG (MW 4000) was added to the bolus material to break the insoluble tannin-protein complexes. Further soluble protein would be released from leaves during rumination, but in the case of sainfoin one would expect that only insoluble tannin-protein complexes would again be formed. Thus in a sainfoin-fed cow no soluble protein can be found in the rumen fluid (Jones \& Mangan, unpublished results) and the putative protein foams which are a primary cause of bloat cannot form.

Jones \& Mangan (1977) in a study of complexes formed between $\mathrm{U}^{14} \mathrm{C}$-labelled $\mathrm{F} 1$ leaf protein and the purified condensed tannin (leucoanthocyanin) from sainfoin, found that the minimum amount of tannin to completely precipitate $\mathrm{F} 1$ leaf protein was $2.5 \mathrm{~mol} / \mathrm{mol}$ protein, but further tannin could be bound, up to $10 \mathrm{~mol} / \mathrm{mol}$ protein, without any excess of tannin being present in solution. In the presence of a large excess of tannin up to $23 \mathrm{~mol}$ could combine with $1 \mathrm{~mol}$ protein. Thus within the range $2 \cdot 5-10 \mathrm{~mol}$ tannin $/ \mathrm{mol} \mathrm{F} 1$ protein neither soluble protein nor soluble tannin would be expected in the rumen fluid of a sainfoin-fed cow. The tannin-F1-protein complexes showed maximum stability in the $\mathrm{pH}$ range 4-7, conditions normally found in the rumen. Barry \& Manley (1986) have shown with $L$. pedunculatus that approximately $90 \%$ of the condensed tannins are precipitated as a complex with leaf protein when the leaves are disintegrated.

The condensed tannin content of $L$. pedunculatus $\mathrm{L}$. and $L$. corniculatus $\mathrm{L}$. varies widely between individual plant populations (Ross \& Jones, 1974) and some individual plants had no flavanols, particularly in the winter time. The flavanol content in L. pedunculatus was invariably higher in summer than in winter for all populations. It was concluded that a fuller understanding of the genetic and environmental factors in flavanol production would be important in any programme of bloat control with tannin-containing forages.

Barry \& Duncan (1984) and Waghorn et al. (1987a) have shown the importance of the condensed tannin concentrations in $L$. pedunculatus and L. corniculatus respectively in the protein nutrition of sheep and this factor would be highly relevant to any system of bloat control. Although some species of tannin-containing forage plants, such as sainfoin, have been used for hundreds of years in Europe and the Middle East, the fact remains that present day use is small, despite efforts to disseminate information, e.g. the Montana Sainfoin Symposium (Cooper \& Charleton, 1968), Harvey (1978) and more recently a symposium on The Future of Sainfoin in British Agriculture' (Grasslands Research Institute, 1982). 


\section{NON-RUMINANT ANIMAL NUTRITION}

In contrast to the position with ruminant animals where tannins in the diet may have considerable benefits, and in plants where tannins give partial protection against predators, in simple-stomached animals, including man, tannins in the diet are generally undesirable, except in small amounts where mild astringency gives 'character' and 'bite' to food or drink. Feeny (1969) clearly showed that the tannins of oak leaves inhibited the tryptic hydrolysis of proteins, the condensed tannin fraction being more effective than the hydrolysable tannin fraction at $\mathrm{pH} 9 \cdot 2$, the $\mathrm{pH}$ found in the midgut of larval Lepidoptera, and near the $\mathrm{pH}$ optimum for tryptic activity ( $\mathrm{pH} 7 \cdot 5-9 \cdot 0)$. Other enzymes, $\beta$-glucosidase, $\alpha$-amylase, $(E C 3.2 .1 .1)$ and $\beta$-amylase $(E C 3.2 .1 .2)$, were known to be inhibited by tannins.

Joslyn \& Glick (1969) showed that the adverse effects of tannins given to rats was due both to reduction in voluntary intake and to toxic effects. Of the hydrolysis products, gallic acid and D-catechin were highly toxic.

Horigome et al. (1988) isolated purified condensed tannins (proanthocyanidins) from the leaves of the fodder plants, black locust (Robinia pseudo-acacia), bush clover (Lespedeza bicolor), wistaria (Wistaria floribunda) and Japanese knotgrass (Reynoutria japonica), and separated them on Sephadex LH-20 into different MW fractions. The inhibitory effects of the tannins on trypsin (EC 3.4.21.4), $\alpha$-amylase and lipase $(E C$ 3.2.1.3) activities in vitro increased with increasing polymerization, as did the protein-precipitating capacity. Inclusion of $10 \mathrm{~g}$ black-locust tannin $/ \mathrm{kg}$ in the diet of rats depressed the trypsin and $\alpha$ amylase activity in the upper, middle and lower parts of the small intestine, but did not depress the lipase activity. In each plant a range of MW species of tannins occurred and this is probably an important factor in biological activity in addition to the total concentration of tannin present.

Jambunathan \& Mertz (1973) in a comparison of six varieties of Sorghum bicolor L. Moench with tannin contents ranging from 4.7 to $68.8 \mathrm{~g} / \mathrm{kg} \mathrm{DM}$, showed that for rats the feed intake and protein consumption was inversely related to the tannin content. The protein efficiency ratio (PER) was also inversely related. Changed distribution of protein fractions in the endosperm and red pigments developed in some fractions indicated the presence of leucoanthocyanins in the endosperm in addition to that in the seed pericarp.

Brown pericarp colour and the presence of a pigmented testa in sorghum grain was found by Maxson et al. (1973) to be correlated with tannins and $\alpha$-amylase inhibitor and negatively correlated to DMD, PER, feed intake and weight gain in rats. $\alpha$-Amylase inhibitor was absent in grains which did not have a pigmented testa. The genes which determined the pigmented testa and the brown pericarp were dominant and were associated with tannin content (Maxson et al. 1972).

Cousins et al. (1981) compared nutrient digestibility of two bird-resistant, high-tannin sorghums (34.0 and $31.7 \mathrm{~g}$ catechin $/ \mathrm{kg} \mathrm{DM}$ ) and two non-resistant, low-tannin varieties ( 8.3 and $8.8 \mathrm{~g}$ catechin $/ \mathrm{kg} \mathrm{DM}$ ) in pigs. Lysine was supplemented to $0.6-0.7 \%$ by addition of casein. The high-tannin varieties showed significantly lower $(P<0.01)$ digestibility of $\mathrm{DM}$, gross energy and $\mathrm{N}$ than the low-tannin varieties. Using pigs with cannulas at the terminal ileum digestibilities with high-tannin varieties were similarly lower $(P<0.01)$ for $\mathrm{DM}$, gross energy, $\mathrm{N}$ and all the individual AA except methionine. Utilization of absorbed $\mathrm{N}$, however, was not reduced with the high-tannin sorghum.

Using pigs with ileal cannulas, Mitaru et al. (1984) also investigated digestion of feeds containing $850 \mathrm{~g}$ sorghum grain $/ \mathrm{kg}$ with high $(47 \cdot 2 \mathrm{~g} / \mathrm{kg})$ and low $(1 \cdot 1 \mathrm{~g} / \mathrm{kg})$ tannin, and $150 \mathrm{~g}$ soya-bean meal $/ \mathrm{kg}$. The high-tannin-sorghum diet showed reduced digestibility for protein and individual AA at the terminal ileum. 'Reconstitution' of the high-tannin- 
sorghum grain (i.e. soaking with $300 \mathrm{~g}$ water containing acetic acid $(20 \mathrm{ml} / \mathrm{l})$-propionic acid $(60: 40, v / v) / \mathrm{kg}$ for $20 \mathrm{~d})$ caused a reduction in tannin, as measured by vanillin- $\mathrm{HCl}$, from 47.3 to $1.0 \mathrm{~g} / \mathrm{kg}$. This was presumed to be due to solubilization, followed by increased polymerization with a large increase in MW. This would be expected to result in reduced reaction with protein, and digestibility studies showed there was a highly-significant difference $(P<0.01)$ between the high-tannin-sorghum diet and the 'reconstituted' diet for protein and all individual AA except methionine. There were no significant differences between the low-tannin, low-tannin reconstituted, and high-tannin reconstituted diets.

Grain sorghum is used extensively in the poultry industry and Fuller et al. (1966) concluded that high-tannin varieties containing 16 or more $\mathrm{g}$ tannin $/ \mathrm{kg}$ had a depressing effect on growth of chicks when fed at $500 \mathrm{~g} / \mathrm{kg}$ diet. Varieties with less than $13 \mathrm{~g}$ tannin/ $\mathrm{kg}$ appeared not to be toxic. The adverse effects of high tannin in sorghums on growth of chickens and also the digestibilities of AA have been amply confirmed (Stephenson et al. 1971; Rostagno et al. $1973 a, b$ ).

The high tannin content of the brown-seeded varieties of sorghum, however, is important in bird and weather resistance, and in some areas cannot be replaced by low-tannin varieties. Sorghum-improvement programmes in Africa emphasize bird resistance in varieties for semi-arid zones. The proanthocyanidin in the grain is concentrated in the pericarp and testa and suitable milling will reduce the tannin content of the meal, but in less-developed areas domestic traditional treatment may have a considerable effect on nutritional value.

Thus Maclean et al. (1981) found that with young children, using two conventional and two high-lysine sorghum varieties, the cooked whole-grain meal was associated with poor weight gain or weight loss. Faecal output was increased 2-5- to 3-fold and plasma AA analysis showed that lysine and threonine were limiting. Poor absorption $(46 \%)$ and retention $(14 \%)$ of dietary energy indicated that all the sorghum whole grains were unsuited to the requirements of young children, 6-30 months of age, who were already under nutritional stress. Apparent $\mathrm{N}$ absorption was only $70 \%$ of that obtained with rice cereal.

In a related study, by Maclean et al. (1983), a conventional sorghum variety from the previous study was milled, decorticated and extruded. The nutrition of young children, 7-24 months of age, on this diet was markedly improved, particularly when lysine was supplemented. Faecal output was reduced to that on the non-sorghum control diet, $\mathrm{N}$ absorption was identical to that of the control diet and $\mathrm{N}$ retention, although less than the casein-based control diet, was within expected values.

Eggum et al. (1983), however, found that low-tannin sorghums (var. Tetron, Dabar and Feterita) had high values for true protein digestibility and digestible energy $(>90 \%)$ in rats. The sorghum protein has low biological value, due mainly to low lysine, a factor common to most cereals. Cooking, to prepare 'Ugali' porridge, decreased the protein digestibility, although its biological value increased. Acidification to $\mathrm{pH} 3.9$ reversed these cooking effects. The starch content of sorghum is higher and fibre content lower than most cereals (Bach Knudsen \& Munck, 1985) but the high tannin content results in large amounts of the protein being bound to the dietary fibre and acid-detergent fibre (ADF) fractions in contrast to other cereals. The ADF-bound protein had the same AA composition as kafirin, the main storage protein, and increased with cooking of the food. Fermentation or acidification to $\mathrm{pH} 3.9$ reduced this fraction.

Bach Knudsen et al. (1988) have studied in detail the effects of cooking, pH, and polyphenol concentration in sorghum on the nutritional value. Three sorghum varieties, Dabar, Feterita and Argentine containing 0, 2.6 and $31.9 \mathrm{~g}$ catechin equivalents $/ \mathrm{kg}$ DM respectively were used. The Argentine variety had tannin in the testa and pericarp and 
Feterita in the testa only. Rat feeding trials were carried out on four treatments: (1) uncooked, (2) uncooked, acidified to $\mathrm{pH} 3 \cdot 9$, (3) cooked porridge ('Ugali'), (4) cooked, acidified to $\mathrm{pH}$ 3.9. Cooking of all species, both at neutral and acid $\mathrm{pH}$, generated appreciable amounts $(8-23 \mathrm{~g} / \mathrm{kg}$ ) of amylase-resistant starch, which then appeared as an increase in dietary fibre. True protein digestibility was reduced by cooking in all three varieties, but with the high-tannin Argentine variety this was very marked, with a reduction of almost $50 \%$. Net protein utilization (NPU) was not significantly affected in Dabar and Feterita, but neutral cooking of the high-tannin variety caused a drastic reduction in NPU. These results were accompanied by corresponding reductions in digestible energy and large increases in faecal DM excretion. Digestibilities of AA were adversely affected by cooking, particularly under neutral conditions, and this was especially so for the high-tannin variety. Reduction in availability of lysine and threonine is particularly undesirable. Acidification, normally induced by fermentation of sorghum diets, had little effect on the low-tannin sorghums, but with Argentine the loss in true digestible protein and AA digestibility by cooking was considerably reduced. Recommended procedures for high-tannin sorghums in East Africa involve solubilizing the tannin with acid or alkaline conditions followed by washing of the grain (Mukura et al. (1982), as quoted by Bach Knudsen et al. (1988)). The desirable function of bird resistance has been clearly associated with the tannin content of the seed (Bullard \& Elias, 1980) using the African red-billed weaver (Quelea quelea) as test animal. The condensed tannin content increased in the developing seed and decreased again at maturity, although bird resistance remained high.

Tannins are present in a wide variety of beans used for human or animal food. Carob (Ceratonia siliqua L.) tannins were shown (Tamir \& Alumot, 1970) to depress growth in rats when added to a commercial diet. Green carob tannin acted by suppression of feed intake, but ripe carob tannin, in addition to depression of feed intake, caused an enhanced faecal output of $\mathrm{N}$ and a high level of stable tannin-protein complexes in the intestines which required treatment with urea $(500 \mathrm{~g} / \mathrm{l})$ to solubilize. Carob-pod extracts were shown (Tagari et al. 1965) to inhibit rumen fermentation reactions in vitro. Cellulolysis, proteolysis, deamination and microbial protein synthesis were strongly inhibited and the tannin fraction was shown to be directly responsible for the effect on proteolysis and protein synthesis. Joslyn et al. (1968) showed that green carob pods contained a mixture of hydrolysable gallotannin and condensed tannin, but the ripe pods contained mainly leucodelphinidins of high MW. These results explained some of the well-documented adverse nutritional effects of carob pods with calves, lactating cows and chickens.

The winged bean (Psophocarpus tetragonolubus L.DC., P. palustris Desr.), used extensively in south-east Asia and Africa contains tannins and trypsin inhibitors which are not destroyed by microwave or dry-oven treatment, but are greatly reduced by infra-red, autoclaving or boiling-water treatment (Kadam et al. 1987).

Jood et al. (1987) have studied the effects of domestic treatments on several varieties of chickpea (Cicer arietinum) ( $n$ ) and blackgram (Vigna mungo) ( $n$ 4). Soaking and cooking gave significant but modest losses of polyphenols, but bigger reductions were obtained with autoclaving, 21-31 and 22-30\% for chickpea and blackgram respectively. Sprouting of the seeds was also effective with losses of 19-28 and 17-20\% respectively. Polyphenol was estimated by the Folin-Dennis reaction after extraction into methanol- $\mathrm{HCl}$ but in common with many other nutritional papers, the nature of the tannins involved was not investigated.

Ford \& Hewitt $(1979 a, b, c)$ used a microbiological assay (Streptococcus zymogenes) for measuring methionine availability and relative nutritional value (RNV) of cereals and pulses. With a range of sorghum varieties $(n 19)$ there was a strong negative correlation between methionine availability and tannin content (catechin) $(r-0.95 ; P<0.001)$. Whiteflowered varieties ( $n$ 11) (no tannin) of field beans (Vicia faba L.) contained more available 
methionine than coloured flowered ( $n$ 11) varieties, and within the coloured-flowered group the available methionine was negatively correlated $(r-0.75 ; P<0.01)$ to the tannin content. The tannin contents of four barley varieties collected from different areas were all low and had a high methionine availability. Treatment with PEG (MW 4000) in vitro increased the mean availability of methionine in high-tannin sorghums from 8.9 to $16.2 \mathrm{~g} / \mathrm{kg}$ protein and increased the RNV from 41 to 78 . With field bean the PEG effect was small and barley showed no response. Prolonged treatment with ammonia ( $7 \mathrm{~d})$ produced results similar to PEG. In vivo tests with both rats and chickens on high-tannin sorghums gave similar results, with large increases in $\mathrm{N}$ digestibility, like these produced by addition of PEG $(100 \mathrm{~g} / \mathrm{kg}$ protein) to the diet or treatment with ammonia. There was some loss in biological value. With field beans there was a significant increase in protein utilization by chickens due to PEG $(P<0.05)$ but only a non-significant effect with rats. Barley showed a high $\mathrm{N}$ digestibility with no PEG effect.

Bond (1976) had shown that coloured-flowered varieties ( $n$ 10) of Vicia faba L. (broad beans, field beans) contain leucoanthocyanins in the seed testa, whereas white-flowered varieties $(n 8)$ are tannin-free. In vitro DM digestibility of the testa was significantly reduced from a mean of $56 \cdot 2$ to $17 \cdot 1 \%$ by the presence of tannin. The cotyledons of all varieties were free from tannin, but the tannins in the testa may be significant in the nutrition of chickens and cattle.

In addition to imposing stress on the digestive system there are other problems with high-tannin diets, such as the possible demographic correlation between oesophageal cancer and bird-resistant high-tannin sorghums (Morton, 1970, 1987) and interference with iron metabolism (Roy \& Mukherjee, 1979a, b, $c$; Hallberg, 1981).

Millets (Pennisetum typhoides, Pennisetum americanum, Setaria italica, Eragrostis tef and many others) are another very important grain crop in semi-arid tropical regions and, although similar to the sorghums and often grouped together, do not contain tannins detectable by vanillin- $\mathrm{HCl}$ (Reichert et al. 1979). Extensive reviews on sorghum and millets have been carried out recently by Rao \& House (1971), Hulse (1980) and Hulse et al. (1980).

\section{TRENDS AND CONCLUSIONS}

There is little doubt that present methods of analysis, in particular combinations of gas-liquid chromatography and HPLC with various forms of MS, will continue to provide detailed information on the complex mixtures of 'tannins' present in plant tissue of interest to nutritionists. Sufficient detailed information on the molecular species present in the tannin complexes, the form they exist in the plant tissues and their release and interaction with dietary proteins and digestive enzymes will enable many nutritional problems of simple-stomached species to be resolved. Some of the problems are purely economic, such as those in the pig and poultry industries of developed countries, but others, for example the dependence on high-tannin sorghums in poorer and often drought-stricken regions are humanitarian and multifactorial. The optimum balance between bird resistance, drought resistance and human nutrition has not been defined and alternatives to high tannin content as a bird repellent should be pursued. The current research on the tannins of semi-arid browse species is encouraging, both in terms of good scientific information and the prospects that the more-desirable species may be utilized to the full and improved. The nutritional inadequacy of some browse species for production in cattle and sheep has been elucidated and with further research may be improved to the benefit of the human population.

The problem of bloat in cattle persists even in agriculturally well-developed countries 
such as the USA and New Zealand, where the high-production dairy cow is particularly vulnerable. The problem is not only economic, but a moral one of animal welfare when large numbers of animals suffer unduly. The development, by genetic manipulation, or conventional plant breeding, of pasture species containing suitable tannins to control soluble-protein concentrations in the rumen without interference with digestion in the small intestine would appear to be most promising. The basic work on Lotus species in New Zealand already indicates good progress both for bloat control and protein nutrition in sheep and could be extended to other tannin-containing legumes such as sainfoin. Recently Meyer et al. (1987) have transformed a petunia mutant with a gene from Zea mays encoding for dihydroquercetin 4-reductase which can reduce dihydrokaempferol to leucopelargonidin which is the precursor of red pelargonidin 3-glucoside pigments, which does not normally occur in this mutant (RL01) of Petunia hybrida. A new pathway was created which produced pelargonidin-3-glycoside and pelargonidin-3-glycosylglycoside and inter alia of leucopelargonidin, related to the condensed tannins. This research approach may therefore offer the promise of generating tannin-containing forage plants based on high-yielding species such as white clover.

Some trifolium species, $T$. affine L. and $T$. avense L., already contain condensed tannins, and other high-production species such as $T$. repens (white clover) and $T$. pratense (red clover) contain tannins in the flower petals which is not expressed in the green leaves. Cocking and co-workers at the Plant Genetic Manipulation Group, Nottingham, have succeeded in isolating mesophyll protoplasts of a number of legume species, Trigonella corniculata (Lu et al. 1982), L. corniculatus (Ahuja et al., 1983a) and T. repens L. and $O$. viciifolia Scop. (Ahuja et al. 1983b) and regenerated functional plants. There are high prospects for producing somatic hybrids between tannin-containing, and therefore bloatsafe species, such as sainfoin and major forage legumes such as lucerne, white and red clovers.

The author is grateful to Dr E. C. Bate-Smith for his interest and many useful discussions and to Dr Brian Heap, Deputy Director of this Institute, for providing facilities.

\section{REFERENCES}

Agricultural Research Council (1980). The Nutrient Requirements of Ruminant Livestock. Farnham Royal: Commonwealth Agricultural Bureaux.

Ahuja, P. S., Hadiuzzaman, S., Davey, M. R. \& Cocking, E. C. (1983a). Prolific plant regeneration from protoplast derived tissues of Lotus corniculatus L. (birds foot trefoil). Plant Cell Reports 2, 101-104.

Ahuja, P. S., Lu, D. Y., Cocking, E. C. \& Davey, M. R. (1983b). An assessment of the cultural capabilities of Trifolium repens L. (white clover) and Onobrychis viciifolia Scop. (sainfoin) mesophyll protoplasts. Plant Cell Reports 2, 269-272.

Ashes, J. R., Mangan, J. L. \& Sidhu, G. S. (1984). Nutritional availability of amino acids from proteins crosslinked to protect against degradation in the rumen. British Journal of Nutrition 52, 239-247.

Asquith, T. N. \& Butler, L. G. (1986). Interactions of condensed tannins with selected proteins. Phytochemistry 25, 1591-1593.

Bach Knudsen, K. E. \& Munck, L. (1985). Dietary fibre contents and composition of sorghum and sorghumbased foods. Journal of Cereal Science 3, 153-164.

Bach Knudsen, K. E., Munck, L. \& Eggum, B. O. (1988). Effect of cooking pH and polyphenol level on carbohydrate composition and nutritional quality of a sorghum (Sorghum bicolor (L.) Moench) food, Ugali. British Journal of Nutrition 59, 31-47.

Barry, T. N. (1985). The role of condensed tannins in the nutritional value of Lotus pedunculatus for sheep. 3. Rates of body and wool growth. British Journal of Nutrition 54, 211-217.

Barry, T. N., Allsop, T. F. \& Redekopp, C. (1986a). The role of condensed tannins in the nutritional value of Lotus pedunculatus for sheep. 5. Effects on the endocrine system and on adipose tissue metabolism. British Journal of Nutrition 56, 607-614.

Barry, T. N. \& Duncan, S. J. (1984). The role of condensed tannins in the nutritional value of Lotus pedunculatus for sheep. 1. Voluntary intake. British Journal of Nutrition 51, 485-491. 
Barry, T. N. \& Manley, T. R. (1984). The role of condensed tannins in the nutritional value of Lotus pedunculatus for sheep. 2. Quantitative digestion of carbohydrates and proteins. British Journal of Nutrition, 51, $493-504$.

Barry, T. N. \& Manley, T. R. (1986). Interrelationships between the concentrations of total condensed tannin, free condensed tannin and lignin in Lotus sp. and their possible consequences in ruminant nutrition. Journal of the Science of Food and Agriculture 37, 248-254.

Barry, T. N., Manley, T. R. \& Duncan, S. J. $(1986 \mathrm{~b})$. The role of condensed tannins in the nutritional value of Lotus pedunculatus for sheep. 4. Sites of carbohydrate and protein digestion as influenced by dietary reactive tannin concentration. British Journal of Nutrition 55, 123-137.

Bate-Smith, E. C. (1954). Leucoanthocyanins. I. Detection and identification of anthocyanidins formed from leucoanthocyanins in plant tissues. Biochemical Journal 58, 122-125.

Bate-Smith, E. C. (1973a). Tannins of herbaceous leguminosae. Phytochemistry 12, 1809-1812.

Bate-Smith, E. C. $(1973 \mathrm{~b})$. Haemanalysis of tannins: the concept of relative astringency. Phytochemistry 12 , 907-912.

Bate-Smith, E. C. \& Lerner, N. H. (1954). Leuco-anthocyanins. 2. Systematic distribution of leucoanthocyanins in leaves. Biochemical Journal 58, 126-132.

Beart, J. E., Lilley, T. H. \& Haslam, E. (1985). Plant polyphenols - secondary metabolism and chemical defence: some observations. Phytochemistry 24, 33-38.

Beasley, T. H., Ziegler, H. W. \& Bell, A. D. (1977). Determination and characterization of gallotannin by high performance liquid chromatography. Analytical Chemistry 49, $238-243$.

Bell, T. A., Etchells, J. L. Singleton, J. A. \& Smart, W. W. G. Jr (1965). Inhibition of pectinolytic and cellulolytic enzymes in cucumber fermentation by sericea. Journal of Food Science 30, 233-239.

Black, J. L., Beaver, D. E., Faichney, G. J., Howarth, B. R. \& Graham, N. McC. (1980-81). Simulation of the effects of rumen function on the flow of nutrients from the stomach of the sheep: Part $I$-description of a computer program. Agricultural Systems 6, 195-219.

Bond, D. A. (1976). In vitro digestibility of the testa in tannin-free field beans (Vicia faba L.). Journal of Agricultural Science, Cambridge 86, 561-566.

Bradfield, A. E. \& Bate-Smith, E. C. (1950). Chromatographic behaviour and chemical structure. Biochimica et Biophysica Acta 4, 441-444.

Broderick, G. A. (1978). In vitro procedures for estimating rates of ruminal protein degradation and proportions of protein escaping the rumen undegraded. Journal of Nutrition 108, 181-190.

Brown, P. J. \& Wright, W. B. (1964). An investigation of the interaction between milk proteins and tea polyphenols. Journal of Chromatography 11, 504-514.

Bullard, R. W. \& Elias, D. J. (1980). Sorghum polyphenols and bird resistance. In Polyphenols in Cereals and Legumes, pp. 43-49. [J. Hulse, editor]. Ottawa: International Development Research Centre.

Burroughs, W. D., Trenkle, A. \& Vetter, R. L. (1974). A system for protein evaluation for cattle and sheep involving metabolizable protein (amino-acids) and urea fermentation potential of feedstuffs. Veterinary Medicine, Small Animal Clinician 69, 713-722.

Clark, R. T. \& Reid, C. S. W. (1974). Foamy bloat of cattle. A review. Journal of Dairy Science 57, 753-785.

Cooper, C. S. \& Charleton, A. E. (1968). Sainfoin Symposium. Bozeman, Montana: Montana State University, Artcraft Printers.

Cope, W. A. \& Burns, J. C. (1971). Relationship between tannin levels and nutritive value of Sericea. Crop Science 11, 231-233.

Cousins, B. W., Tanksley, T. D., Knabe, D. A. \& Zebrowska, T. (1981). Nutrient digestibility and performance of pigs fed sorghums varying in tannin concentration. Journal of Animal Science 53, 1524-1537.

Czochanska, Z., Foo, L. Y., Newman, R. H. \& Porter, L. J. (1980). Polymeric proanthocyanidins. Stereochemistry, structural units and molecular weights. Journat of the Chemical Society, Perkin Transactions 1 , $2278-2286$

Czochanska, Z., Foo, L. Y., Newman, R. H., Porter, L. J., Thomas, W. A. \& Jones, W. T. (1979). Direct proof of a homogeneous polyflavan-3-ol structure for polymeric proanthocyanidins. Journal of the Chemical Society, Chemical Communications 8, 375-377.

Demarquilly, C. \& Weiss, P. (1970). Tableau de la valeur alimentaire des fourrages (Table of the nutritional value of forages). Etude no. 41. Versailles: INRA-SEI.

D'Mello, J. P. F. \& Fraser, K. W. (1981). The composition of leaf meal from Leucaena leucocephala. Tropical Science 23, 75-78.

Egan, A. R. \& Ulyatt, M. J. (1980). Quantitative digestion of fresh herbage by sheep. VI. Utilization of nitrogen in five herbages. Journal of Agricultural Science, Cambridge 94, 47-56.

Eggum, B. O., Monowar, L., Bach Knudsen, K. E., Munck, L. \& Axstell, J. (1983). Nutritional quality of sorghum and sorghum foods from Sudan. Journal of Cereal Science 1, 127-137.

Feeny, P. P. (1969). Inhibitory effect of oak leaf tannins on the hydrolysis of proteins by trypsin. Phytochemistry 8, 2119-2126.

Ferguson, K. A., Hemsley, J. A. \& Reis, P. J. (1967). Nutrition and wool growth. The effect of protecting dietary protein from microbial degradation in the rumen. Australian Journal of Science 30, 215-217.

Ford, J. E. \& Hewitt, D. (1979a). Protein quality in cereals and pulses. I. Application of microbiological and other 
in vitro methods in evaluation of rice (Oryza sativa L.), sorghum (Sorghum vulgare Pers.), barley and field beans (Vicia faba L.). British Journal of Nutrition 41, 341-352.

Ford, J. E. \& Hewitt, D. $(1979 \mathrm{~b})$. Protein quality in cereals and pulses. 2. Influence of polyethylene glycol on the nutritional availability of methionine in sorghum (Sorghum vulgaris Pers.), field beans (Vicia faba L.) and barley. British Journal of Nutrition 42, 317-323.

Ford, J. E. \& Hewitt, D. $(1979 \mathrm{c})$. Protein quality in cereals and pulses. 3. Bioassays with rats and chickens on sorghum (Sorghum vulgare Pers.), barley and field beans. Influence of polyethylene glycol on digestibility of the protein in high-tannin grain. British Journal of Nutrition 42, 325-340.

Foo, L. Y. \& Porter, L. J. (1980). The phytochemistry of proanthocyanidin polymers. Phytochemistry 19, $1747-1754$.

Fox, D. G., Sniffen, C. J., Van Soest, P. J. \& Robinson, P. H. (1979). A computerized net protein system for formulating rations for beef and dairy cattle, using feed analysis data. Proceedings of the Cornell Nutrition Conference for Feed Manufacturers, pp. 57-62.

Fuller, H. L., Potter, D. K. \& Brown, A. R. (1966). The feeding value of grain sorghums in relation to their tannin content. University of Georgia, College of Agriculture Experiment Station. Bulletin N.S. 176, pp. 5-14. Athens, Georgia: University of Georgia.

Goldstein, J. L. \& Swain, T. (1963). Changes in tannins in ripening fruit. Phytochemistry 2, $371-383$.

Grasslands Research Institute (1982). The Future of Sainfoin in British Agriculture. Proceedings of meeting, 12 Oct 1982.

Haddock, E. A., Gupta, R. K., Al-Shaf, S. M. K., Lyden, K., Haslam, E. \& Magnolato, D. (1982). The metabolism of gallic acid and hexahydroxydiphenic acid in plants. Biogenic and molecular taxonomic considerations. Phytochemistry 21, 1049-1062.

Hagerman, A. E. \& Butler, L. G. (1978). Protein precipitation method for the quantitative determination of tannins. Journal of Agricultural and Food Chemistry 26, 809-812.

Hallberg, L. (1981). Bioavailability of dietary iron in man. Annual Review of Nutrition 1, $123-147$.

Harborne, J. B., Mabry, T. J. \& Mabry, H. (eds) (1975). In The Flavonoids, Parts 1 and 2. New York: Academic Press.

Harvey, G. (1978). A nice touch of Sainfoin. Farmers Weekly Sept. 22.

Hulse, J. H. (ed.) (1980). Polyphenols in Cereals and Legumes. Ottawa: International Development Research Centre.

Hulse, J. H., Laing, E. M. \& Pearson, O. E. (1980). Sorghum and the Millets: Their Composition and Nutritive Value. London: Academic Press.

Horigome, T., Kumar, R. \& Okamoto, K. (1988). Effects of condensed tannins prepared from leaves of fodder plants on digestive enzymes in vitro and in the intestines of rats. British Journal of Nutrition 60, $275-285$.

Jacques, D., Haslam, E., Bedford, G. R. \& Greatbanks, D. (1973). Structure of the dimeric proanthocyanidin-A2 and its derivatives. Journal of the Chemical Society, Chemical Communications 15, 518-520.

Jambunathan, R. \& Mertz, E. T. (1973). Relationship between tannin levels, rat growth and distribution of proteins in sorghum. Agricultural and Food Chemistry 21, 692-696.

Jarrige, R., Journet, M. \& Vérité, R. (1978). Azote (nitrogen). Alimentation des Ruminants. INRA Publication. 78000 . Versailles.

John, A. \& Lancashire, J. A. (1981). Aspects of the feeding and nutritive value of Lotus species. Proceedings of the New Zealand Grassland Association 42, 152-159.

Jones, W. T., Anderson, L. B. \& Ross, M. D. (1973). Bloat in cattle. 39. Detection of protein precipitants (flavolans) in legumes. New Zealand Journal of Agricultural Research 16, 441-446.

Jones, W. T., Broadhurst, R. B. \& Lyttleton, J. W. (1976). The condensed tannins of pasture legume species. Phytochemistry 15, 1407-1409.

Jones, W. T. \& Lyttleton, J. W. (1969). Bloat in cattle. 29. The foaming properties of clover proteins. New Zealand Journal of Agricultural Research 12, 31-46.

Jones, W. T., Lyttleton, J. W. \& Clark, R. T. J. (1970). Bloat in cattle. 33. The soluble proteins of legume forages in New Zealand and their relationship to bloat. New Zealand Journal of Agricultural Research 13, 149-156.

Jones, W. T. \& Mangan, J. L. (1977), Complexes of the condensed tannins of the sainfoin (Onobrychis viciifolia Scop.) with Fraction 1 leaf protein and with submaxillary mucoprotein, and their reversal by polyethylene glycol and $\mathrm{pH}$. Journal of the Science of Food and Agriculture 28, 126-136.

Jood, S., Chauhan, B. M. \& Kapoor, A. C. (1987). Polyphenols of chickpea and blackgram are affected by domestic processing and cooking methods. Journal of the Science of Food and Agriculture 39, $145-149$.

Joslyn, M. A. \& Glick, Z. (1969). Comparative effects of gallotannic acid and related phenolics on the growth of rats. Journal of Nutrition $98,119-126$.

Joslyn, M. A., Nishira, H. \& Ito, S. (1968). Leucoanthocyanins and related phenolic compounds of carob pods (Ceratonia siliqua). Journal of the Science of Food and Agriculture 19, 543-550.

Kadam, S. S., Smithard, R. R., Eyre, M. D. \& Armstrong, D. G. (1987). Effects of heat treatments on antinutritional factors and quality of proteins in winged bean. Journal of the Science of Food and Agriculture 39, 267-275.

Kaufmann, W. (1977), Calculation of the protein requirements for dairy cows according to measurements of $\mathrm{N}$ - 
metabolism. In Protein Metabolism and Nutrition. European Association of Animal Production Publication no. 22, pp. 130-132. Wageningen: Centre for Agricultural Publishing and Documentation.

Kendall, W. A. (1966). Factors affecting foams with forage legumes. Crop Science 6, 487-489.

Le Houérou, H. N. (ed.) (1980). Chemical composition and nutritive value of browse in tropical West Africa. In Browse in Africa. The Current State of Knowledge. Addis Ababa, Ethiopia: International Livestock Centre for Africa.

Lu, D. Y., Davey, M. R. \& Cocking, E. C. (1982). Somatic embryogenesis from mesophyll protoplasts of Trigonella corniculata (Leguminosae). Plant Cell Reports 1, 278-280.

Mabry, T. J. \& Markham, K. R. (1975). Mass spectrometry of flavonoids. In The Flavonoids, pp. $78-126$ [J. B. Harborne, T. J. Mabry and H. Mabry, editors]. New York: Academic Press.

McArthur, J. M., Miltimore, J. E. \& Pratt, M. J. (1964). Bloat investigations. The foam stabilizing protein of alfalfa. Canadian Journal of Animal Science 44, 200-206.

McDonald, I. W. \& Hall, R. J. (1957). The conversion of casein into microbial proteins in the rumen. Biochemical Journal 67, 400-405.

Maclean, W. C. Jr, De Romana, G. L., Gastanaduy, A. \& Graham, G. G. (1983). The effect of decortication and extrusion on the digestibility of sorghum by preschool children. Journal of Nutrition 113, 2071-2077.

Maclean, W. C. Jr, De Romana, G. L., Placko, P. \& Graham, G. G. (1981). Protein quality and digestibility of sorghum in preschool children: balance study and plasma free amino acids. Journal of Nutrition 111, $1928-1936$.

McLeod, M. N. (1974). Plant tannins-their role in forage quality. Nutrition Abstracts and Reviews 44, $803-815$.

Mangan, J. L. (1959). Bloat in cattle. 11. The foaming properties of proteins, saponins and rumen liquor. New Zealand Journal of Agriculiural Research 2, 47-61.

Mangan, J. L. (1972). Quantitative studies on nitrogen metabolism in the bovine rumen. The rate of proteolysis of casein and ovalbumin and the release and metabolism of the amino acids. British Journal of Nutrition 27, 261-283.

Mangan, J. L. (1982). The nitrogenous constituents of fresh forage. In Forage Protein in Ruminant Animal Production, British Society of Animal Production Occasional Publications no. 6, pp. 25-40 [D. J. Thompson, D. E. Beever and R. G. Gunn, editors]. Thames Ditton: British Society of Animal Production.

Mangan, J. L., Vetter, R. L., Jordan, D. J. \& Wright, P. C. (1976). The effect of the condensed tannins of sainfoin (Onobrychis viciaefolia) on the release of soluble leaf protein into the food bolus of cattle. Proceedings of the Nutrition Society 35, 95A.

Marks, D., Glyphis, J. \& Leighton, M. (1987). Measurements of protein in tannin-protein precipitates using ninhydrin. Journal of the Science of Food and Agriculture 38, 255-261.

Marshall, D. R., Broue, P. \& Munday, J. (1979). Tannins in pasture legumes. Australian Journal of Experimental Agriculture and Animal Husbandry 19, 192-197.

Martin, J. S. \& Martin, M. M. (1983). Tannin assays in ecological studies. Precipitation of ribulose-1,5bisphosphate carboxylase/oxygenase by tannic acid, quebracho and oak foliage extracts. Journal of Chemical Ecology 9, $285-294$.

Martin, M. M., Rockholm, D. C. \& Martin, J. S. (1985). Effects of surfactants, pH and certain cations on precipitation of proteins by tannins. Journal of Chemical Ecology 11, 485-494.

Maxson, E. D., Clark, L. E., Rooney, L. W. \& Johnson, J. W. (1972). Factors affecting the tannin content of sorghum grain as determined by two methods of tannin analysis. Crop Science 12, 233-235.

Maxson, E. D., Rooney, L. W, Lewis, R. W., Clark, L. E. \& Johnson, J. W. (1973). The relationship between tannin content, enzyme inhibition, rat performance and characteristics of sorghum grain. Nutrition Reports International 8, 145-152.

Meyer, P., Heidmann, I., Forkmann, G. \& Saedler, H. (1987). A new petunia flower colour generated by transformation of a mutant with a maize gene. Nature 330, 677-678.

Mitaru, B. N., Reichert, R. D. \& Blair, R. (1984). The binding of dietary protein by sorghum tannins in the digestive tract of pigs. Journal of Nutrition 114, 1787-1796.

Morton, J. F. (1970). Tentative correlations of plant usage and esophageal cancer zones. Economic Botany 24, $217-226$.

Morton, J. F. (1987). Tannin and oesophageal cancer. Lancet i, 327-328.

Mueller-Harvey, I., McAllan, A. B., Theordorou, M. K. \& Beaver, D. E. (1988). Phenolics in fibrous crop residues and plants and their effects on digestion and utilization of carbohydrates and proteins in ruminants. Plant Breeding and the Nutritive Value of Crop Residues. Addis Ababa, Ethiopia: International Livestock Centre for Africa.

Mueller-Harvey, I., Reed, J. D. \& Hartley, R. D. (1987). Characterisation of phenolic compounds, including flavonoids and tannins, of ten Ethiopian browse species by high performance liquid chromatography. Journal of the Science of Food and Agriculture 39, 1-14.

Muir, L. A., Wien, S., Duquette, P. F., Rickes, E. L. \& Cordes, E. H. (1983). Effect of exogenous growth hormone and diethylstilbestrol on growth and carcase composition of growing lambs. Journal of Animal Science 56, $1315-1323$. 
Murdiati, T. B. \& McSweeney, C. S. (1987). Binding properties of hydrolysable tannins to proteins. Proceedings of the 2nd International Symposium on the Nutrition of Herbivores, pp. 41-42 [M. Rose, editor]. Brisbane: University of Queensland.

Murdiati, T. B., McSweeney, C. S. \& Lowry, J. B. (1987). Hydrolysable tannins in forages: metabolism in sheep. Proceedings of the 2 nd International Symposium on the Nutrition of Herbivores, pp. 45-46 [M. Rose, editor]. Brisbane: University of Queensland.

Nugent, J. H. A. \& Mangan, J. L. (1981). Characteristics of the rumen proteolysis of fraction 1 (18S) leaf protein from lucerne (Medicago sativa L.). British Journal of Nutrition 46, 39-58.

Nishimuta, J. F., Ely, D. G. \& Boling, J. A. (1974). Ruminal bypass of dietary soybean protein treated with heat, formalin and tannic acid. Journal of Animal Science 39, 952-957.

Osbourn, D. G., Terry, R. A., Cammell, S. B. \& Outen, G. E. (1971). The effect of leuco-anthocyanins in sainfoin (Onobrychis viciifolia L.) on the availability of protein to sheep and upon the determination of the acid detergent fibre and lignin fractions. Proceedings of the Nutrition Society 30, 13 A.

Pierpoint, W. S. (1983). Reactions of phenolic compounds with proteins and their relevance to the production of leaf protein. In Leaf Protein Concentrates, pp. 235-267 [L. Telek and H. D. Graham, editors]. Connecticut: AVI Publishing Co.

Purchas, R. W. \& Keogh, R. G. (1984). Fatness of lambs grazed on Grassland Maku lotus and Grasslands Huia white clover. Proceedings of the New Zealand Society of Animal Production 44, 219-221.

Rao, N. G. P. \& Housse, A. R. (1971). Sorghum in the Seventies. New Delhi, India: Oxford and IBH Publishing Co.

Reed, J. D., Horvath, P. J., Allen, M. S. \& Van Soest, P. J. (1985). Gravimetric determination of soluble phenolics including tannins from leaves by precipitation with trivalent ytterbium. Journal of the Science of Food and Agriculture 36, 255-261.

Reed, J. \& Soller, H. (1987). Phenolics and nitrogen utilization in sheep fed browse. Proceedings of the 2 nd International Symposium on the Nutrition of Herbivores, pp. 47-48 [M. Rose, editor]. Brisbane: University of Queensland.

Reichert, R. D., Youngs, C. G. \& Christensen, D. A. (1979). Polyphenols in Pennisetum millet. In Polyphenols in Cereals and Legumes [J. H. Hulse, editor]. Ottawa: International Development Research Centre.

Reid, C. S. W., Johns, A. T. \& Vlieg, P. (1961). Bloat in cattle. 22. Further experiments on treatment and prevention. New Zealand Journal of Agricultural Research 4, 476-483.

Reis, P. J. \& Tunks, D. A. (1969). Evaluation of formaldehyde-treated casein for wool growth and nitrogen retention. Australian Journal of Agricultural Research 20,775-781.

Ribéreau-Gayon, P. (1972). Plant Phenolics. Edinburgh: Oliver \& Boyd.

Ross, M. D. \& Jones, W. T. (1974). Bloat in cattle. 40. Variation in flavanol content of Lotus. New Zealand Journal of Agricultural Research 17, 191-195.

Rostagno, H. D., Featherston, W. R. \& Rogler, J. C. (1973a). Studies on the nutritional value of sorghum grains with varying tannin contents for chicks. I. Growth studies. Poultry Science 52, 765-772.

Rostagno, H. D., Rogler, J. C. \& Featherston, W. R. (1973b). Studies on the nutritional value of sorghum grains with varying tannin contents for chicks. 2. Amino acid digestibility studies. Poultry Science 52, 772-778.

Roy, S. N. \& Mukherjee, S. (1979a). Influence of food tannins on certain aspects of iron metabolism. I. Absorption and excretion in normal and anaemic rats. Indian Journal of Biochemistry and Biophysics 16 , 93-98.

Roy, S. N. \& Mukherjee, S. $(1979 b)$. Influence of food tannins on certain aspects of iron metabolism. I1. Storage and transport in normal and anaemic rats. Indian Journal of Biochemistry and Biophysics 16, 99 -104.

Roy, S. N. \& Mukherjee, S. $(1979$ c). Influence of food tannins on certain aspects of iron metabolism. III. Heme synthesis and haematopoiesis in normal and anaemic rats. Indian Journal of Biochemistry and Biophysics 16 , $151-157$.

Self, R., Eagles, J., Galletti, G. C., Mueller-Harvey, I., Hartley, R. D., Lea, A. G. H., Magnolato, D., Richli, U., Guger, R. \& Haslam, E. (1986). Fast atom bombardment mass spectrometry of polyphenols (syn. vegetable tannins). Biomedical and Environmental Mass Spectrometry 13, 449-468.

Smart, W. W. G. Jr, Bell, T. A., Stanley, N. W. \& Cope, W. A. (1961). Inhibition of rumen cellulase by an extract from Sericea forage. Journal of Dairy Science 44, 1945-1946.

Stephenson, E. L., York, J. O., Bragg, D. B. \& Ivy, C. A. (1971). The amino acid content and availability of different strains of grain sorghum to the chick. Poultry Science 50, 581-584.

Stifel, F. B., Vetter, R. L., Allen, R. S. \& Horner, H. T. (1968). Chemical and ultrastructural relationships between alfalfa leaf chloroplasts and bloat. Phytochemistry 7, 355 .

Tagari, H., Henis, Y., Tamir, M. \& Volcani, R. (1965). Effect of carob pod extract on cellulolysis, proteolysis, deamination and protein biosynthesis in an artificial rumen. Applied Microbiology 13, 437-442.

Tamir, M. \& Alumot, E. (1970). Carob tannins-growth depression and levels of insoluble nitrogen in the digestive tract of rats. Journal of Nutrition 100, 573-580.

Ulyatt, M. J., Lancashire, J. A. \& Jones, W. T. (1977). The nutritive value of legumes. Proceedings of the New Zealand Grassland Association 38, 107-118. 
Van Hoven, W. (1984). Tannins and digestibility in Greater Kudu. Canadian Journal of Animal Science 64, Suppl. $177-178$

Waghorn, G. C., John, A., Jones, W. T. \& Shelton, I. D. (1987a). Nutritive value of Lotus corniculatus L. containing low and medium concentrations of condensed tannins for sheep. Proceedings of the New Zealand Society of Animal Production 47, 25-30.

Waghorn, G. C., Ulyatt, M. J., John, A. \& Fisher, M. T. (1987 b). The effect of condensed tannins on the site of digestion of amino acids and other nutrients on sheep fed on Lotus corniculatus L. British Journal of Nutrition 57, $115-126$.

Wilson, A. D. (1977). The digestibility and voluntary intake of the leaves of trees and shrubs by sheep and goats. Australian Journal of Agricultural Research 28, 501-508.

Zelter, S. Z., LeRoy, F. \& Tissier, J. P. (1970). Protection des protéînes alimentaires contre la désamination bactérienne dans le rumen (Protection of feed proteins against bacterial deamination in the rumen). Annales de Biologie Animale Biochimie Biophysique 10, 123-141. 